\title{
AJARAN MORAL KERIS JAWA
}

\author{
Nurhadi Siswanto *)
}

\begin{abstract}
ABSTRACK
Java is so exotic. Java is beautiful. Being a Javanese as well as being any ethnicity, is not a curse but a gift from God. Cultural values and wisdom not just tales of the parents alone, but it is a fact. One thing that is quite interesting to examine the Javanese is the existence of an heirloom called "keris". Keris has a long background history for the Javanese community. Keris, in the past was made with full of philosophy, made with a hope, desire, or even an ideal of thebuyer so that the keris as a final product reflects and represents all things non-objects of the buyer. in Javanese keris contains many values and moral teachings. The values implicit in Javanese keris, include : (1) the doctrine of religiousity and awareness of the limitations of human power (2) subjects to be always humble an not arrogant (3) theaching to always live in harmoni with nature (4) the doctrine for living in harmony with fellow human, and (5) the doctrine of dynamism in life.
\end{abstract}

Keywords: Teachings, Keris , Java

\section{ABSTRAK}

Jawa itu sangat eksotis. Jawa itu indah. Menjadi Jawa serta menjadi etnis manapun, bukanlah kutukan tapi hadiah dari Tuhan. Nilai-nilai budaya dan kearifan bukan hanya cerita orang tua saja, tapi itu adalah fakta. Satu hal yang cukup menarik untuk memeriksa orang Jawa adalah adanya pusaka yang disebut "keris". Keris memiliki latar belakang sejarah yang panjang bagi masyarakat Jawa. Keris, di masa lalu itu dibuat dengan penuh filsafat, dibuat dengan harapan, keinginan, atau bahkan ideal-pembeli sehingga keris sebagai produk akhir mencerminkan dan mewakili semua hal-hal non- benda pembeli. dalam keris Jawa mengandung banyak nilai-nilai dan ajaran moral. Nilai-nilai yang tersirat dalam keris Jawa, meliputi: (1) doktrin religiusitas dan kesadaran akan keterbatasan daya manusia (2) pelajaran untuk selalu rendah hati yang tidak sombong (3) theaching untuk selalu hidup dalam harmoni dengan alam (4) doktrin untuk hidup harmonis dengan sesama manusia, dan (5) ajaran tentang dinamika dalam kehidupan.

Kata kunci: Ajaran, Keris, Jawa

\section{PENDAHULUAN}

Jawa memang eksotik. Jawa itu indah. Menjadi orang Jawa sebagaimana menjadi orang dari etnis manapun, bukanlah suatu kutukan, melainkan sebuah anugrah dari Tuhan. Nilai dan budaya kearifannya bukan sekedar dongengan orang-orang tua belaka, tetapi merupakan sebuah fakta. Fakta yang hingga saat ini

\footnotetext{
* Nurhadi Siswanto, Staf Pengajar Program Studi Kriya Seni, Jurusan Kriya, Fakultas Seni Rupa, Institut Seni Indonesia Yogyakarta
} 
masih bisa diketahui jejak dan keberadaannya ${ }^{1}$. Fakta yang telah menghasilkan ribuan karya ilmiah dan penelitian. Fakta yang telah menghantarkan ratusan orang menjadi sarjana, master dan doktor. Banyak hal yang telah dikaji dan dikupas tentang Jawa, namun Jawa tidak pernah hilang daya tariknya untuk terus dan terus dikaji dan dipelajari.

Salah satu hal yang cukup menarik untuk di kaji dan diteliti tentang orang Jawa adalah keberadaan sebuah benda pusaka yang bernama "keris". Keris memiliki latar sejarah yang panjang bagi masyarakat Jawa. Pulau Jawa yang dahulu masih berbentuk kerajaan selalu memiliki benda-benda pusaka yang terdiri dari olahan "Wesi Aji"; baik terdiri dari emas, perak, tembaga dan jenis logam-logam lainnya. Wesi Aji yang berbentuk keris, tombak dan benda lainnya sering disebut benda-benda pusaka yang dikeramatkan ${ }^{2}$. Sejarah kepemimpinan dan kekuasaan yang pernah terjadi di pulau Jawa mencatat berbagai peristiwa perebutan kekuasaan di Jawa, hampir dapat dipastikan bahwa perebutan kekuasaan yang ada selalu ditandai hadirnya keris atau benda pusaka lainnya, dalam konteks ini, secara jelas, keris menjadi simbol kekuasaan ${ }^{3}$.

Keris pada masa lalu dibuat dengan penuh filosofi, dibuat dengan suatu harapan, keinginan, atau bahkan suatu cita-cita dari si-pemesan sehingga keris sebagai suatu produk akhir mencerminkan dan melambangkan semua hal non-benda dari si pemesan tersebut. Pada masa lampau, empu pembuat keris sangat dihormati dan dikenang orang sepanjang zaman ${ }^{4}$. Empu keris mempersatukan keinginan sang pemesan keris dengan kekuatan alam raya yang terwujudkan dalam simbol-simbol keris hasil karyanya. Apa yang diciptakan oleh seorang empu dalam membabar (membuat) sebilah keris adalah suatu cetusan daya cipta yang diwujudkan oleh hentakan-hentakan palu diatas paron, sehingga terwujudlah detildetil manifestasi maksud yang dipadatkan dalam bentuknya yang abstrak pada lempengan besi, baja, dan nikel (meteorik). Pemadatan kehendak yang dirangkum dalam doa khusuk seorang ahli tapabrata (pertapa), maka akan terlahirlah sutu bilah keris.

Tujuan pembuatan keris bermacam-macam, ada keris yang dibuat dengan harapan agar pemiliknya selalu dalam kondisi kecukupan rejeki, ada pula harapan akan status sosial yang baik, tidak jarang pula keris dibuat dengan harapan agar si pemilik terhindar dari bencana atau gangguan makhluk halus. Pembuatan keris mungkin pula dilakukan untuk memperingati suatu saat yang bersejarah atau mempunyai arti istimewa bagi pemesan atau pemiliknya, atau sebagai tanda tali kasih maupun penghargaan dari si pemesan kepada orang lain yang telah dianggap berjasa kepadanya. Oleh karena itulah keris-keris masa lalu selalu unik dan tidak ada yang sama satu dengan lainnya. Kalaupun mungkin ada kemiripan secara fisik, tetapi secara non-bendawi keris tersebut pastilah berbeda.

\section{PEMBAHASAN}

\section{A. Mencari Ajaran Moral dibalik Simbol Keris Jawa}

Kata moral (Inggris : moral), dari bahasa Latin moralis ----- mos, moris (adat, istiadat, kebiasaan, cara, tingkah laku, kelakuan), mores (adat istiadat, kelakuan, 
tabiat, watak, akhlak, dan cara hidup). Istilah moral mengandung beberapa pengertian yaitu (1) Menyangkut kegiatankegiatan manusia yang dipandang sebagai baik/buruk, benar/salah, tepat/tidak tepat. (2) Sesuai dengan kaidah-kaidah yang diterima menyangkut apa yang dianggap benar, bijak, adil dan pantas. (3) Memiliki kemampuan untuk diarahkan oleh (dipengaruhi oleh) keinsyafan akan benar dan salah, serta memiliki kemampuan untuk mengarahkan (mempengaruhi) orang lain sesuai dengan kaidah-kaidah perilaku yang dinilai benar atau salah (4) Menyangkut cara seseorang bertingkah laku dalam hubungan dengan orang lain ${ }^{5}$.

Filsafat Moral berarti filsafat yang mengkaji tetang moral atau lebih sering dikenal dengan istilah Etika. Etika berasal dari bahasa Yunani ethikos, ethos (adat, kebiasaan, praktek). Secara terminologi Etika menyangkut : (1). Nilainilai (values) dan norma-norma (norms) yg menjadi pegangan bagi seseorang atau kelompok untuk mengatur tingkah lakunya. (2). Kumpulan asas (principles) atau nilai moral (moral value) atau kode etik. (3). IImu tentang yang baik atau buruk, bermoral atau tidak bermoral. Etika disebut sebagai moral philosophy.

Etika berarti filsafat mengenai bidang moral, atau ilmu atau refleksi sistematik mengenai pendapat-pendapat, norma-norma dan istilah-istilah moral. Secara lebih luas etika merupakan keseluruhan norma dan penilaian yang dipergunakan oleh masyarakat yang bersangkutan untuk mengetahui bagaimana manusia seharusnya menjalankan kehidupannya ${ }^{6}$.

Etika bukan suatu sumber tambahan bagi ajaran moral, melainkan merupakan filsafat atau pemikiran kritis dan mendasar tentang ajaran-ajaran dan pandangan-pandangan moral. Etika adalah sebuah ilmu, bukan sebuah ajaran. Antara etika dan ajaran moral tidak berada pada tingkat yang sama, yang menyatakan bagaimana kita harus hidup, bukan etika melainkan ajaran moral. Etika hendak mengerti mengapa kita harus mengikuti ajaran moral tertentu, atau bagaimana kita dapat mengambil sikap yang bertanggungjawab berhadapan dengan berbagai ajaran moral ${ }^{7}$.

Moralitas sebagai entitas abstrak merupakan potensi kerohanian dari kehidupan suatu masyarakat, yang menjadikan masyarakat itu memiliki sistem nilai budaya (culture values system) yang merupakan petujuk setiap warga untuk bersikap dan bertingkah laku dalam kehidupan sehari-hari. Moralitas identik dengan sistem nilai budaya yang berlaku dalam lingkungan masyarakat tertentu. Suatu sistem nilai budaya terdiri dari konsepsi-konsepsi, yang hidup dalam alam pikiran sebagian besar dari warga masyarakat, mengenai hal-hal yang harus dianggap sangat bernilai dalam kehidupan $^{8}$.

Secara harfiah keris diartikan sebagai senjata tajam yang bilahnya berlekuk-lekuk atau lurus, biasanya diberi sarung dan dianggap bertuah. Kata keris berasal dari awalan ke dan kata iris, yang bila digabungkan berarti alat untuk memotong sesuatu. Keris adalah sejenis senjata tajam tradisional di beberapa daerah di Indonesia seperti Jawa, Madura, Bali, Sumatra, Sulawesi Selatan, bermata tajam pada kedua belah sisinya. Keris Jawa dianggap sebagai suatu lambang kepahlawanan $^{9}$

Seorang bangsawan di lingkungan keraton Surakarta, Pangeran 
Hadiwidjojo, pernah mengatakan bahwa kata keris berasal dari bahasa Jawa kuno yang dijabarkan dari akar kata kris, dalam bahasa Sanskrit yang berarti menghunus. Seorang guru besar agama Islam di Yogyakarta Ki Moesa Al Mahfoed, berpendapat bahwa kata keris berasal dari kata haris (bahasa Arab), yang berarti "penjaga keselamatan diri"10.

Keris dalam bahasa Jawa jarwadhasa adalah 'kekeran aris'. Kekeran berarti pagar, penghalang, peringatan dan pengendalian. Aris berarti tenang, hatihati, dan halus. Keris berarti seseorang dalam berhubungan dengan sesama manusia dapat saling ngeker atau memagari, memperingatkan dan mengendalikan diri secara aris, jangan sampai memamerkan dirinya ${ }^{11}$.

Keris adalah senjata tikam khas Indonesia. Berdasarkan dokumendokumen purbakala, keris dalam bentuk awal telah digunakan sejak abad ke-9. Kuat kemungkinannya bahwa keris telah digunakan sebelum masa tersebut. Keris diperkirakan sudah mulai dibuat di Indonesia, di Pulau Jawa, pada abad ke-5 atau ke-6. Tentunya dalam bentuk yang masih sederhana. Keris mencapai bentuknya seperti yang kita kenal sekarang diperkirakan baru pada sekitar abad ke-12 atau abad ke-13. Budaya keris mencapai puncaknya pada zaman kerajaan Majapahit. Budaya keris menyebar sampai ke daerah Palembang, Riau, Semenanjung Malaya, Brunei Darussalam, Filipina Selatan, Kamboja atau Champa, bahkan sampai ke daerah Surathani dan Pathani di Thailand bagian selatan ${ }^{12}$ (Harsrinuksmo, 2004: 27)

Keris yang merupakan sebuah hasil karya cipta para empu yang dibuat dengan maksud dan makna tertentu mengandung nilai-nilai ajaran kehidupan yang dalam bagi manusia Jawa. Ajaran atau nilai-nilai tersebut tentunya dapat dikatagorikan sebagai nilai-nilai filosofis tentang ajaran hidup dan kehidupan. Pemaknaan keris dalam kehidupan orang Jawa semestinya tidak hanya dipandang sebagai senjata tikam saja, tetapi perlu dikaji makna simbolik yang tersimpan dibalik wujud fisiknya $^{13}$ (Gustami, 2007: 56). Ajaranajaran moralitas Jawa akan sangat terlihat bila pemahaman makna-makna simbolis yang ada pada keris dapat dirumuskan.

Ajaran-ajaran moral yang terselip dalam simbol-simbol pada keris tentunya merupakan local wisdom dan local genius yang luar biasa yang dapat dijadikan sebagai pengkayakan wacana tentang pendidikan karakter bagi para generasi penerus bangsa. Kearifan orang Jawa yang tersimbolkan dalam bentuk keris akan nampak sangat indah bila dikaitkan dengan pendidikan kharakter bangsa. Nenek moyang kita adalah generasi yang waskita yang mengajarkan berbagai ajaran tentang kehidupan yang baik yang tersimbolkan dari sebilah keris Jawa. Analisis filosofis yang mendalam dengan menggunakan metodologi hertmenetik yang penulis lakukan, dicoba untuk dibangun dan dirumuskan filsafat moral keris Jawa.

Filsafat moral keris dalam pengertian ini, adalah merupakan upaya reflektif dari penulis untuk merumuskan ajaran-ajaran moral dari keris Jawa, dari berbagai uraian data tentang keris direfleksikan secara logis dan rasional sehingga dapat tersusun ajaran-ajaran moral yang bersumber dari keberadaan keris Jawa. Asumsi dasar perumusan ajaran-ajaran moral keris tersebut didasarkan fakta bahwa keris bukan sekedar senjata tajam, tetapi keris 
merupakan hasil olah rasa dan karsa sang empu sesuai permintaan sang pemesan dengan menggunakan cara-cara dan kaidah-kaidah tertentu yang penuh simbol dan makna dalam kehidupan orang Jawa. Hal ini menjadi dasar keyakinan bahwa didalam keris Jawa termuat berbagai ajaran dan pelajaran yang bersifat simbolis, termasuk didalamnya tentang ajaran-ajaran moral bagi orang Jawa

\section{B. Ajaran Moral Keris Jawa}

Keris merupakan senjata tajam (tusuk), sebagai sebuah senjata tajam maka keris mencerminkan sebuah kekuatan, keperkasaan, kegagahan, keberanian maupun kekuasaan. Bahkan senjata tajam juga menyimbolkan sebuah kengerian dan keseraman, namun memperhatikan bentuk keris berbagai kesan tersebut menjadi tidak ada. Keris yang dibentuk dengan berbagai model, dengan berbagai hiasan dengan teknik penggarapan yang luar biasa lebih mengesankan keris sebagai sebuah benda hiasan, kesan keris sebagai senjata tajampun menjadi hilang. Hal ini tentunya bukan merupakan hal yang bersifat kebetulan, namun keris Jawa muncul sebagai ekspresi budaya manusia Jawa yang penuh dengan makna dan tanda. Penulis dengan menggunakan metota refleksi dan heuristika mencoba merumuskan berbagai ajaran moral yang terkandung dalam sebilah keris Jawa sebagai berikut.

\section{Ajaran Tentang Religiusitas dan Kesadaran akan Keterbatasan Kekuatan Manusia}

Kuatnya nuansa religius keris Jawa telah tercermin dalam awal pembuatannya. Proses pembuatan keris diawali dengan sikap dan pemahaman dari sang empu maupun sang pemesan keris bahwa kekuatan yang dimiliki manusia sangatlah terbatas, sehingga dalam upaya mewujudkan keinginan dan harapannya manusia harusnya memohon petunjuk dan keberkahan dari yang maha kuat.

Bagi orang Jawa alam empiris berhubungan erat dengan alam meta empiris (alam gaib), mereka saling meresapi. Alam empiris selalu sudah diresapi oleh alam gaib. Alam inderawi bagi orang Jawa merupakan ungkapan alam gaib, yaitu misteri berkuasa yang mengelilingnya, daripadanya ia memperoleh eksistensinya dan ia bergantung ${ }^{14}$.

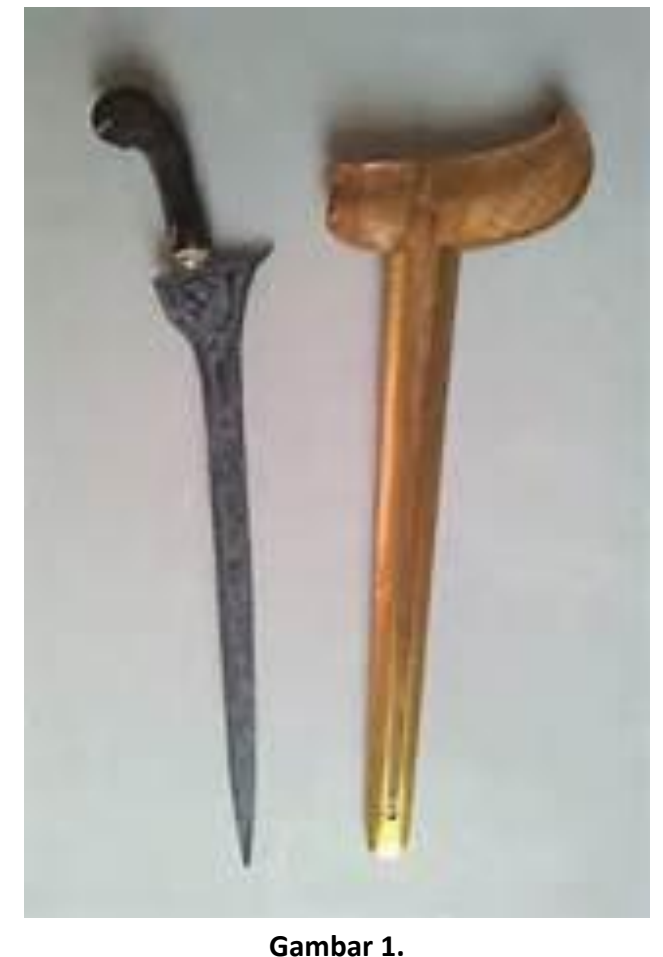

Keris merupakan pe-ngejawantahan-an dari filosofi Ke-Tuhan-an orang Jawa dengan adanya istilah "curigo manjing warangka warangka manjing curiga" sebuah seni bangun yang indah dan mengandung makna "kemanungnggalan KawuloGusti" 
Keris dalam budaya Jawa dipandang sebagai sebuah pusaka yang mencerminkan filsafat ketuhanannya. Keris merupakan pe-ngejawantahan-an dari filosofi Ke-Tuhan-an orang Jawa dengan adanya istilah "curigo manjing warangka" (bilah bersatu dengan sarung keris) dan "warangka manjing curiga" (sarung keris menyatu dengan bilahnya), sebuah seni bangun yang indah dan mengandung makna "kemanungnggalan Kawulo-Gusti" (bersatunya hamba dengan Tuhannya).

Menyatu dengan Tuhan dapat diartikan sebagai pengakuan dan kesadaran tentang keberadaan dan kemahakuasaan Tuhan. Sudah seharusnya manusia menyatukan dirinya dengan Tuhannya, menyamakan kehendak dirinya dengan kehendak Tuhannya. Mengenal Tuhan sesungguhnya mengenal dirinya sendiri dan orang yang tidak mengenal dirinya tidak akan pernah mengenal Tuhannya, sehingga manusia hendaklah selalu mengingat Tuhannya, karena dengan mengingat Tuhan itulah manusia baru bisa menjadi manusia.

Falsafah Jawa mengajarkan bahwa "weruh marang pangeran iku, ateges weruh marang awake dhewe, lamun during weruh awake dhewe, tangeh lamun weruh marang pangeran...Gusti iku dumunung ana jeneng sira pribadi, dene ketemune gusti lamun sira tansah eling". Mengenal adanya Tuhan berarti sudah mengenal dirinya sendiri, jikalau belum mengenal dirinya sendiri, mustahil dapat mengenal Tuhan...Tuhan itu ada dalam dirimu sendiri dan pertemuan dengannya akan terjadi jika engkau senantiasa ingat kepadanya.

Seorang empu keris yang membuat pusaka, dianggap melaksanakan perkawinan antara bapa angkasa (ayah angkasa) dan ibu pratala (ibu bumi). Pamor yang asalnya dari angkasa (batu meteor) dicampur, dijadikan satu, dikawinkan dengan besi yang asalnya dari bumi. Maka dari itu, pembuatan keris merupakan suatu perbuatan mistik sakral, yang harus dikerjakan dengan segala ketekunan dan pengabdian. Maka keris Jawa merupakan simbol bersatunya yang gaib dengan yang fisik, manunggalnya yang fisik dengan yang meta-fisik, dan mengandung tanda-tanda kebesaran Tuhan yang Maha Kuasa.

Manusia dalam kehidupannya
tidaklah akan mampu mengatasi persoalannya yang dihadapinya tanpa kemurahan dari Tuhannya, sehingga ingatan dan gambaran bahwa manusia hidup seperti sedang mengarungi lautan yang luas juga menjadi simbolisasi dari keris Jawa. Tanpa kekuatan dan keteguhan terhadap keimanan dan ketuhanan manusia akan terus terombang-abing dalam kehiidupan dunia, sehingga manusia harusnya selalu eling dan wasdapa terhadap yang transenden.

Tuhan adalah penguasa dari segala yang ada, karena segala yang ada, ada karena kehendak-Nya, maka dalam menjalani kehidupannya sudah seharusnya manusia menyadari tentang kelemahan dan ketidakberdayaannya, dengan memohon bantuan pada Tuhanlah segala persoalan kehidupan akan dapat terpecahkan. Hajad dan keinginan manusia hendaklah diselaraskan dengan ketentuan Tuhan, hal ini akan bisa terjadi bila manusia selalu mendekat pada Tuhannya.

Kesadaran manusia akan keterbatasan kekuatan yang dimilikinya, sehingga selalu menyertakan kekuatan yang lain (Tuhan), merupakan bekal hidup yang paling baik untuk keselamatan badan, jiwa dan ruh manusia. Tujuan hidup didunia yang sekedar mampir ngombe atau 
sementara akan menjadi lebih bermakna bila selalu menyertakan yang transenden dalam kehidupannya.

Keberadaan dapur dan pamor keris yang mengisyaratkan adanya tuah tertentu, sesungguhnya adalah sebuah pengakuan kelemahan kekuatan manusia, serta pengakuan dan pengharapan limpahan kekuatan transenden. Sang empu pembuat keris hanyalah berikhtiyar dengan segenap laku spiritual memohon kepada penguasa alam agar keris ciptaannya diberikan kekuatan yang bisa memberikan kebaikan bagi sang pemesan. Kesadaran ini tentunya sebagai upaya pengakuan bahwa ketentuan penguasa alam tidak ada yang bisa menandinginya. "Ora ana kasekten sing madhani papesthen, awit papesten iku wis ora ana sing bisa murungake" (tidak ada kesaktian yang bisa menyamai kepastian Tuhan, karena tidak ada yang dapat menggagalkan kepastian Tuhan.

Ajaran pentingnya sikap dan sifat religius juga tercermin dari peran dan fungsi keris pada asal muasalnya. Sebagaimana telah dijelaskan dalam babbab sebelumnya, bahwa salah satu fungsi keris adalah sebagai benda sesaji. Keberadaan benda sesaji memberikan pengetahuan bahwa manusia Jawa mengakui keberadaan kekuatan diluar dirinya, untuk memperoleh keamanan, kenyamanan dan keselamatan maka manusia hendaklah menyelaraskan diri dan kekuatannya dengan kekuatan diluar dirinya. "Pangeran iku dudu dewa utawa manungsa, nanging sakabehing kang ana iki, uga dewa lan manungsa, asale saka Pangeran" (Tuhan itu bukan dewa atau manusia, namun segala yang ada ini, termasuk dewa dan manusia, itu berasal dari Tuhan).

\section{Ajaran Tentang Rendah Hati dan Ketidak-sombongan}

Bentuk keris Jawa yang dibuat indah penuh pesona dengan berbagai hiasan (dapur dan pamor) telah menghilangkan kesan keseraman dan kegagahan dari sebuah senjata tajam, hal inimerupakan pesan simbolis yang mengajarkan bahwa manusia Jawa hendaklah selalu menjadi manusia yang rendah hati, dan tidak bersifat atau bersikap sombong dengan memamerkan kehebatan dan kekuatan yang dimilikinya. Orang yang baik adalah orang yang selalu berpenampilan dan berperilaku indah, artinya bahwa setiap keinginan, kekuatan, kemampuan yang dimilikinya bukan untuk dipamerpamerkan, melainkan sedapat mungkin disamarkan dengan sifat dan sikap yang lemah lembut dan rendah hati.

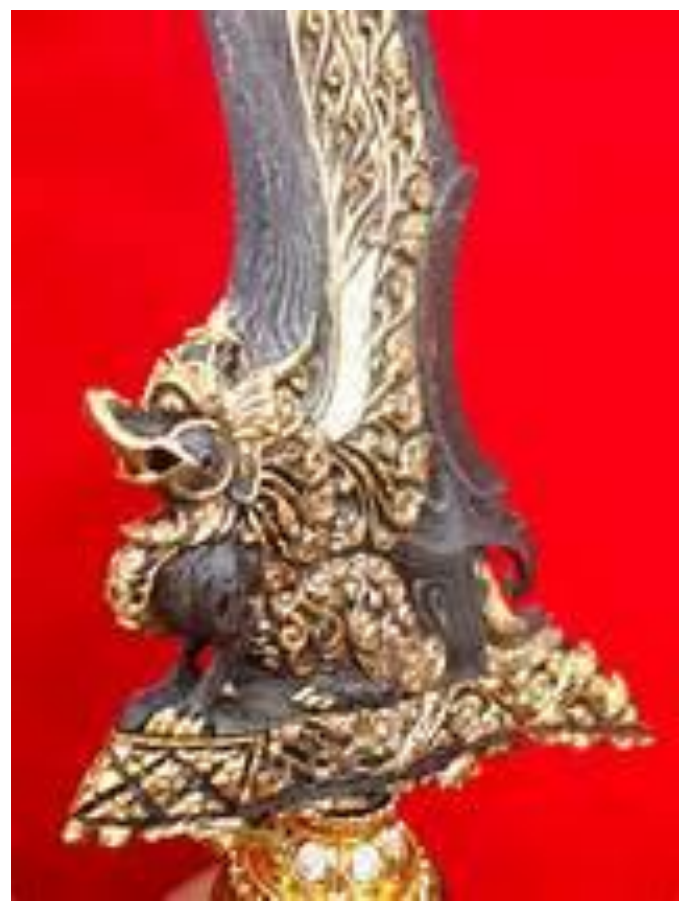

Gambar 2.

Wujud keris yang indah menghilangkan kesan kekerasannya sebagai benda tajam. Hal ini mengajarkan tentang pentingnya rendah hati 
Dapur dan pamor keris merupakan wujud dan cerminan dari keinginan, harapan, tujuan, maksud dan manfaat yang disimbolisasikan oleh sang empu. Dapur dan pamor keris di dalamnya tersirat berbagai keinginan, harapan, kekuatan tekad, dan cita-cita, namun berbagai hal tersebut tidaklah ditampilkan secara vulgar atau terbuka sehingga akan memberikan kesan sebuah kesombongan atau kecongkakan. Orang hendaklah selalu memoles atau mengungkapkan maksud, harapan, keinginan, tekad, kekuatan, tujuan maupun cita-cita nya sedemikian rupa sehingga nampak lebih indah sebagaimana keindahan pada bilah keris yang dihiasi dengan dapur dan pamornya.

Dapur keris sering kali menampilkan bentuk-bentuk binatang buas seperti Naga, Harimau, Srigala, Kera ataupun bentul bentuk yang lain, bentuk-bentuk tersebut mencerminkan adanya keperkasaan, kekuatan dan keampuhan dari bilah keris, namun bentuk-bentuk binatang buas tersebut juga divisualisasikan dalam keindahan tertentu, dengan hiasan tertentu pula sehingga kesan keseraman menjadi berkurang.

Selain menyamarkan berbagai kekuatan dan kelebihan sebagai senjata tajam dalam keindahan dapur dan pamornya, kekuatan dan kelebihan keris juga disembunyikan dengan keberadaan warangka atau sarung keris. Setiap keris memiliki warangka, secara praktis warangka keris berfungsi sebagai pelindung bilah keris, namun secara filosofis warangka keris mengajarkan bahwa kehebatan dan keperkasaan keris bukan untuk di pamer-pamerkan, kehebatan itu harus disamarkan dengan menyembunyikannya pada warangka yang ada.

Orang yang baik hendaknya selalu menghindari kesan kesombongan pribadi dan selalu berupaya untuk mengutamakan kerukunan dan keselarasan dalam hidup. Sifat dan sikap sombong adalah perilaku yang membawa dan menyebabkan sakit hati dan rasa tidak enak pada orang lain, hal yang demikian tentunya akan menggagu kerukunan dan keselarasan dalam hidup manusia.

Prinsip kerukunan bertujuan untuk mempertahankan masyarakat dalam keadaan harmonis, Rukun berarti berada dalam keadaan selaras, tenang dan tenteram, tanpa perselisihan dan pertentangan dan bersatu dalam maksud untuk saling membantu. Kata rukun juga menunjuk pada cara bertindak. Berlaku rukun berarti menghilangkan tanda-tanda ketegangan dalam masyarakat atau antara pribadi-pribadi sehingga hubunganhubungan sosial tetap kelihatan selaras dan baik. Rukun mengandung usaha terus menerus oleh semua individu untuk bersikap tenang satu sama lain dan untuk menyingkirkan unsur-unsur yang mungkin menimbulkan perselisihan dan keresahan $^{15}$.

Kesombongan, suka pamer dan sikap vulgar merupakan hal yang sangat tidak terpuji karena sifat dan sikap tersebut dapat menimbulkan ketegangan dan keresahan sehingga dapat merusak kerukunan dan keselarasan. Sikap dan perilaku yang tidak vulgar (semu/simbolis/tersamar) merupakan bentuk kehalusan budi, dengan cara yang demikian diharapkan jarak sosial dan 
keretakan dalam masyarakat dapat dihindari. Setiap manusia mempunyai tempatnya dan nasib tertentunya sendiri, dan dengan segala kesibukannya tidak bisa mengubah apa-apa padanya. Mampu menahan diri dan mawas diri merupakan suatu keutamaan atau tindakan yang baik.

Ajaran untuk tidak sombong dan tidak suka pamer, juga tersirat dalam sikap dan perilaku orang Jawa terhadap keris. Tabu bagi seseorang untuk mengetahui atau milihat keris yang dimiliki orang lain. Bila seseorang karena berbagai hal ingin mengetahui atau melihat keris yang dimiliki seseorang maka ia harus minta izin terlebih dahulu untuk diperkenankan melihat, bila sang pemilik tidak berkenan maka tabu baginya untuk memaksakan keinginan dan kehendaknya.

Akibat negatif yang ditimbulkan dengan sikap suka pamer terhadap pusaka keris yang dimiliiki juga tercermin pada berbagai kisah yang menggambarkan dampak negatif yang ditimbulkan bila seseorang sombong dengan keris yang dibawa atau dimilikinya. Sebagai contoh kisah kesombongan dan suka pamer yang dilakukan oleh Kebo ljo sahabat Ken Arok ketika dipinjami Keris Empu Gandring, sifat suka pamer itu telah mengakibatkan ia harus menerima hukuman dalam kasus terbunuhnya Akuwu Tunggul Ametung. Walaupun Kebo ljo tidak melakukan perbuatan tersebut namun ia terkena dampak dari perbuatannya yang sombong dan suka pamer keris yang bukan miliknya.

Manusia dalam kehidupannya, hendaklah selalu bersikap rendah hati, karena dengan rendah hati itu pula manusia akan bisa hidup harmonis dengan manusia lainnya. Kesombongan dan keangkuhan karena merasa memiliki kehebatan dan kekuatan yang lebih dibandingkan dengan orang lain, tidak akan memberikan manfaat kecuali kecelakaan dan bahaya baginya dalam mengarungi lautan kehidupan yang sangat luas ini.

Hulu keris yang merupakan stilisasi dari bentuk manusia pada umumnya dibentuk dengan kepala menunduk, hal ini mengajarkan kepada manusia Jawa, hendaklah mengarungi lautan kehidupan dengan menunduk. Hidup menunduk dapat dipahami sebagai simbolisasi dari sikap dan sifat untuk selalu rendah hati, juga dapat dipahami sebagai simbolisasi agar manusia selalu melihat orang-orang dibawahnya sehingga bisa menjadi orang yang selalu bersyukur.

Keris adalah simbol dari kekuatan dan kekuasaan, namun tangkai keris bentuk stilisasi orang yang menundukkan kepala, hal ini tentunya juga merupakan sebuah ajaran bahwa setiap manusia yang berkuasa atau memiliki kekuatan maka sendaklah kekuatan atau kekuasaan itu dipegang dengan kepala menunduk. Hal ini berarti mengandung ajaran bahwa setiap orang yang berkuasa jangan lah sombong, jalankan dan peganglah kekuasaan dengan kepala yang menunduk atau dengan kerendahatian, maka kekuasaan itu akan aman baik bagi yang memegang ataupun bagi orang disekitarnya. " Ratu kang ngegungake pepak gegamane ora kajan uripe, marga kawulane wedi yen dipateni" (penguasa yang hanya membanggakan kekuatan persenjataan tidak akan terhormat hidupnya, karena rakyatnya takut kalau dibunuh).

Pemimpin harus patuh kepada raja yang ada dalam dirinya, yaitu hati. Hati adalah raja tubuh manusia yang amat menentukan segalanya, karena itu seorang pemimpin perlu memperhatikan penyakit hati yang mungkin timbul. Diantara 
penyakit hati tersebut antara lain nafsu ingin berkuasa terus menerus, kumingsun (sombong diri), dan ingin menag sendiri. Tindakan semacam ini, bukan dilandasi hati yang terdalam (nurani) ${ }^{16}$.

\section{Ajaran tentang Keselarasan Hidup}

Filsafat hidup orang Jawa bertolak dari pemikiran cinta pada kesempurnaan, sehingga filsafat Jawa merupakan sarana bagi manusia Jawa untuk mencapai kesempurnaan hidup. Esensi dari filsafat hidup orang Jawa adalah bahwa manusia itu harus mampu menjaga dan menjalin keharmonisan antara hubungan manusia dengan manusia, hubungan manunia dengan alam semesta lingkungannya, dan hubungan antara manusia dengan tuhan Yang Maha Esa. Ajaran filsafat hidup ini juga tersimbolkan dalam keris jawa. Keharmonisan hubungan manusia dengan Tuhan tercermin dari ajaran religiusitasnya, sedangkan ajaran tentang keharmonisan manusia dengan alam serta keharmonisan manusia dengan manusia tergambarkan sebagai berikut :

\section{a. Ajaran untuk Hidup Selarah dengan Alam}

Wujud, bagian, dan nama-nama keris Jawa selalu identik dengan keadaan atau fenomena dan nama-nama alam disekitar. Istilah-istilah yang digunakan pada keris maupun ricikannya juga namanama benda baik makhluk hidup maupun benda mati yang dari alam yang ada di sekitar. Hal yang demikian mengajarkan kepada kita bahwa manusia Jawa adalah manusia yang harus menyelaraskan diri dan hidupnya dengan alam semesta.

Alam semesta dalam pandangan orang Jawa bukanlah sesuatu yang harus dikuasai sehingga bisa dieksploitasi sesuka hati, alam adalah tempat manusia hidup dan memperoleh kehidupan, sehingga keseimbangan dan kelestarian alam haruslah terus dijaga dan dipertahankan bukan untuk dirusak dan dipergunakan secara semena-mena. Memanfaatkan apa yang ada di alam secara baik dan tidak berlebih-lebihan merupakan hal yan sangat penting agar kehidupan manusia tidak merugi. Kehebatan yang dimiliki manusia tidaklah sebanding dengan kehebatan alam semesta sehingga rasa ingin menguasai alam justru berakibat buruk bagi manusia.

Bagi orang Jawa, untuk mempertahankan kehidupannya, orang tidak dapat melepaskan dirinya dari lingkungan tempat hidupnya. la akan selalu bergantung dan berinteraksi dengan lingkungan hidupnya secara terus menerus. Sejak kecil orang Jawa telah akrab bergaul dengan alam yang melingkupi dirinya, lewat proses belajar dan pengalamannya, disadarinya bahwa alam dapat mengancam dan menghancurkan kehidupannya. Orang harus menyadari bahwa keberhasilan hidupnya tergantung dari kekuatankekuatan alam, sehingga orang Jawa mengajarkan bahwa alam bukan untuk dikuasai, tetapi orang harus menyesuaikan dirinya dengan kehidupan alam yang serba gaib, serta harus menjaga keselarasan atau harmoni dengan alam.

Kehidupan manusia akan menjadi lebih baik dalam artian tenteram dan nyaman bila manusia bisa menyelaraskan diri dan kehidupannya dengan alam dimana ia tinggal. Pengetahuan dan pemahaman tentang fenomena dan gejala alam sangatlah penting, sehingga orang Jawa memiliki berbagai rumus dan perhitungan tersendiri tentang alam, musim dan sebagainya. 
Dapur, pamor, ricikan keris dibuat dengan selalu mengambil dari fenomena alam sekitar tentunya bukan hal yang kebetulan, namun hal tersebut dipilih dan dibuat dengan maksud dan tujuan tertentu serta menyimbolkan sesuatu yang memiliki makna dan tujuan yang tertentu pula. Keadaan keris yang demikian tentunya hal tersebut mengajarkan bahwa orang Jawa umumnya atau pemilik keris khususnya haruslah menyelaraskan dirinya dengan alam.

Kecintaan dan kesadaran untuk berselaras dengan alam amat sangat dibutuhkan untuk kelangsungan hidup manusia sekarang dan anak-turun manusia yang akan datang. Tanpa adanya kesadaran ini maka manusia akan bersikap dan berperilaku seenaknya terhadap alam semesta, eksploitasi dan pengrusakan alam akan semakin tidak terkendali, dan semua hal itu akan merugikan manusia itu sendiri.

Eksploitasi alam secara berlebihan akan menimbulkan dampak negatif yang luar biasa bagi hajad hidup manusia. Kerusakan alam lingkungan yang semakin menjadi mengakibatkan berbagai bencana yang merugikan umat manusia, oleh karenanya berlaku bijak terhadap alam dengan mengutamakan keselarasan hidup dengan alam sangatlah berfaedah bukan sekedar terhadap pelestarian alam semesta, namun juga terhadap ketentraman dan kenyamanan hidup umat manusia.

\section{b. Ajaran keselarasan hidup sesama manusia}

terdapat dua kaidah dasar kehidupan dalam pola pergaulan, dalam kehidupan sosial masyarakat Jawa, yaitu : (1) Hendaklah seseorang dapat bersikap sedemikian rupa sehingga tidak sampai menimbulkan konflik; (2) bagaimana dalam cara berbicara dan membawa diri seseorang selalu menunjukkan sikap hormat terhadap orang lain, sesuai dengan derajat dan kedudukannya. Prinsip kerukunan dan menghormati merupakan kerangka normatif yang menentukan bentuk-bentuk nyata semua interaksi. Prinsip kerukunan bertujuan untuk menciptakan masyarakat yang harmonis. Rukun berarti berada dalam keadaan selaras, tenang, dan tenteram, tanpa perselisihan dan pertentangan, serta bersatu untuk bermaksud saling membantu. Rukun adalah keadaan ideal yang diharapkan dapat dipertahankan, dalam semua hubungan sosial, keluarga, rukun tetangga, di desa, dalam setiap pengelompokan tetap. Berperilaku rukun berarti menghilangkan tanda-tanda ketegangan dalam masyarakat atau diantara pribadi-pribadi, sehingga hubungan-hubungan social kelihatan selaras dan baik-baik saja ${ }^{17}$.

Ada dua hal yang perlu diperhatikan dalam tuntutan kerukunan. Pertama, bagaimana menciptakan suatu keadaan untuk tidak mengganggu suatu keselarasan yang diandaikan sudah ada. Ketenangan dan keselarasan sosial yang dapat dianggap normal apabila tidak ada pihak-pihak yang diganggu. Kedua, menjaga keselarasan dalam pergaulan dengan melihat dan memperhitungkan posisi dan kedudukan masing-masing.

Simbolisasi yang ada pada keris Jawa banyak yang mengarah pada ajaran keselarasan hidup sesama manusia. Sebagaimana contoh adalah pada keriskeris yang mengunakan dapur Pudhak Sategal. Simbolisasi pudhak sategal adalah ajaran moralitas pada orang Jawa agar bisa seperti pohon atau daun pudhak (pandan) satu kebun. Daun pandan yang nampak 
tumbuh liar di pekarangan memiliki banyak fungsi dalam kehidupan manusia, salah satu fungsi itu ialah daun pandan dapat digunakan untuk wewangian pada ruangan atau makanan. Daun pandan mengeruarka aroma yang harus dan segar, hal ini merupakan simbolisasi agar dalam kehidupannya manusia Jawa hendaklah melakukan hal hal yang baik (wangi), bagi dirinya, keluarganya maupun masyarakat sekitarnya. Dengan melakukan hal-hal yang baik itulah maka manusia akan dapat menjaga keselarasan hidupnya dengan manusia lainnya.

Orang hidup didunia harusnya menjadi orang yang bermanfaat bagi orang lain. Perbuatan saling tolong dan membatu serta bergotong-royong merumakan perbuatan yang mulia, karena dengan membantu dan menolong orang lain berarti kita telah bermanfaat bagi orang lain yang berarti pula kita telah menebarkan kebaikan dan keharuman di sekitar kita.

Tuah atau kekuatan magis yang diharapkan ada pada sebuah keris yang tersimbolisasikan lewat warangka, hulu, luk, dapur, maupun pamor keris selalu diarahkan dapat bermanfaat bagi bukan hanya kepada pemiliknya, namun juga bagi keluarga, dan masyarakat sekitarnya. Harapan untuk dapat disenangi orang lain dan lingkungannya merupakan cerminan harapan terjadinya keselarasan dalam kehidupan sosial.

Perbuatan untuk saling bantu, saling tolong, dan ingin selalu disenangi orang lain merupakan sebagain kecil dari perilaku untuk dapat mewujudkan keselaran hidup manusia dengan manusia lainnya. Seseorang yang ingin disenangi oleh orang lain, juga harus bersifat dan bersikap menjaga dan mengekang keinginan- keinginan pribadinya, dan menampilkannya dengan cara yang indah sehingga hawa negatif yang ditimbulkannya menjadi hilang.

Penyatuan keinginan,harapan, kehendak, dan tujuan antara sang empu dengan pemesan keris dalam proses pemesanan dan pembuatan keris dapat pula dipamahi sebagai simbolisasi dari pentingnya keselarasan hidup sesama manusia. Suatu konflik biasanya pecah apabila kepentingan-kepentingan yang saling bertentangan bertabrakan, untuk menghindari hal tersebut hendaklah manusia Jawa selalu mementingkan kompromi dan keselarasan kepentingan dan harapannya dengan kepentingan dan harapan orang lain dan masyarakat pada umumnya.

Keselarasan hidup sesama manusia juga tercermin dari kerelarasan antara hulu dan warangka keris. Keselarasan dalam bentuk ukuran, warna dan hiasan yang pas dan cocok antara luhu keris dengan bilah keris ataupun antara hulu keris dengan warangka keris serta bilah keris dengan warangka keris juga merupakan simbolisasi bahwa dalam kehidupannya manusia Jawa haruslah seimbang dan selaras sehingga enak untuk dipandang dan dirasakan.

Konflik sosial sering kali terjadi karena sifat dan sikap ingin menang sendiri atau merasa paling benar. Keris Jawa secara simbolis mengajarkan bahwa sifat dan sikap ingin menang sendiri atau merasa paling benar adalah perbuatan yang tidak baik yang bisa menimbulkan keretakan sosial. Segala sesuatu ada tempatnya, dan seyogyanya segala sesuatu itu didudukkan pada kedudukannya. Setiap rincikan keris Jawa memiliki posisi dan kedudukannya masing-masing, sehingga setiap rincikan atau bagian dari keris Jawa 
akan menimbulkan akibat dan konsekuensi secara semestinya.

Keselarasan hidup sesama umat manusia tentunya pula didukung dan didasari sifat menundukkan diri dan menghiasi sikap dan perilaku sacara manis. Stilisasi manusia yang menundukkan kepala pada hulu keris Jawa selain mengajarkan pentang pentingnya menjalani kehidupan serta memegang kekuasaan dengan kerendahhatian, tentunya juga menyimbolkan tentang pentingnya hidup secara selaras antara manusia. Artinya keselarasan hidup sesame manusia akan bisa terwujud bila masingmasing kita memiliki sifat dan sikap suka menundukkan kepala, menjalani kehidupan dan menjalankan kekuasaan dengan kerendah hatian yang tersimbolkan dengan stilisasi hulu keris Jawa berupa manusia yang menundukkan kepala.

\section{Ajaran tentang Kedinamisan Hidup}

Ajaran tentang kedinamisan hidup tercermin dari jumlah luk keris yang selalu ganjil (gasal). Angka ganjil banyak mewarnai kehidupan orang Jawa, orang Jawa sering menganggap angka satu, tiga, lima, tujuh, dan Sembilan sebagai refleksi budaya sakral. Masing-masing angka tersebut, memiliki implikasi yang sangat luas. Misalkan saja bilangan satu dikaitkan dengan Kang Maha Tunggal (Tuhan), manunggal (nyawiji) yaitu penyatuan dua unsur. Angka tiga juga dihubungkan dengan tradisi : nelung dino, triloka, tripusara, trikawula busana, trisunthi winayang kari, tritata, dan sebagainya. Bilangan lima terimplikasi pada konsep Pandawa, Pancadarma, Lima Pancer, dan sebagainya. Angka tujuh terkait dengan mitung dina, bumi langit sap pitu, pitung gajah lan pitung gunung, turun pitu dan sebagainya. Bilangan Sembilan, terkait dengan babahawan hawa sanga ${ }^{18}$.

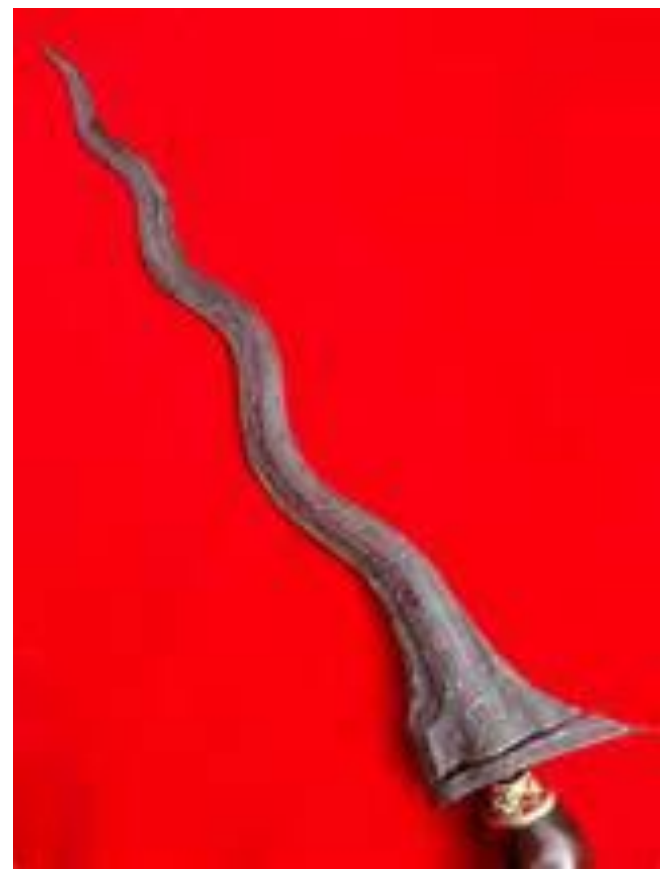

Gambar 3.

Jumlah luk keris selalu berjumlah ganjil.

Gasal atau ganjil pada luk keris bisa diartikan sebagai sesuatu yang berkelanjutan, dinamis, dan lambang ambisi untuk maju.

Dalam budaya Jawa terdapat falsafah yang menyiratkan bahwa sesuatu yang telah genap berarti telah selesai dan tidak berkembang lagi. Sementara sesuatu yang gasal atau ganjil berarti sesuatu itu belum genap, dan harus digenabkan atau dilanjutkan. Dengan demikian, gasal atau ganjil pada luk keris bisa diartikan sebagai sesuatu yang berkelanjutan, dinamis, dan lambang ambisi untuk maju.

Manusia dalam kehidupannya, membutuhkan semangat, harapan, keinginan, dan impian untuk terus berkembang dan maju, karena tanpa semangat, harapan, keinginan, dan impian tersebut hidup menjadi terasa hampa. Hidup yang dinamis dan berkesinambungan akan memberikan perasaan senang dan terus maju dan 
berkembang. Kedinamisan dan semangat untuk terus maju merupakan bekal yang sangat penting dan fundamental dalam upaya mengarungi samudra kehidupan yang sangat luas. Tanpa hal tersebut maka orang akan merasa mati, hidupnya tidak memiliki fungsi lagi.

Filosofi Jawa yang tercermin dalam pepatah alon-alon waton kelakon, bukanlah cerminan untuk tidak bersemangat terus maju. Filosofi ini tetaplah mengarah pada kedinamisan hidup yang terus menerus, namun harus diiringi singan sifat dan sikap hati-hati dan teliti, karena apapun yang dipilih dan dilakukan manusia dalam kehidupannya akan berdampak pada dirinya, dan harus dipertanggungjawabkannya.

Semangat untuk terus maju dan berkembang dalam kehidupannya juga tercermin pada banyaknya harapan yang ada pada simbol-simbol pamor keris. Seseorang yang memiliki harapan tertentu, maka ia menginginkan ada sesuatu tertenntu dikelak kemudian hari. Namun bagi orang Jawa ambisi kemajuan dan peningkatan sesuatu hendaklah dirumuskan dan dilakukan dengan baik tanpa harus merusak dan menyakiti orang lain. Keinginan untuk maju yang ditampilkan secara vulgar dan berlebihan akan menggagu orang lain sehingga dapat mengakibatkan rusaknya kerukunan hidup yang telah ada dalam kehidupan kemasyarakatan Jawa.

Keinginan dan ambisi untuk maju bagi orang Jawa juga harus dibalut dengan sifat religiusitas. Karena kerterbatasan kekuatan dan daya upaya manusia, maka jika manusia tidak menggantungkan harapan dan keinginannya terhadap yang transenden akan berdampak kurang positif. Keinginan dan harapan manusia haruslah pula diselaraskan dengan keinginan dan kemurahan dari yang transenden (Tuhan).

\section{Daftar Bacaan}

Budisutrisna, 2009, Gambaran Manusia Dalam Keris, dalam Joko Siswanto (ed), Kearifan Nusantara, Kepel Press, Yogyakarta

Daryono, 2007, Etos Dagang Orang Jawa Pengalaman Raja Mangkunagara IV, Pustaka Pelajar, Yogyakarta.

Djoko Sukiman, 1983, Keris: Sejarah dan Fungsinya, Javanologi, Yogyakarta

Hadisiswaya, AM., 2009, Filosofi Wahyu Keraton Rahasia Dibalik Cerita, Simbolis dan Lambang Keraton Jawa, C.V. Sahabat, Klaten

Hasan Sadhily, 1990, Ensiklopedia Indonesia, PT Ichtiar Baru, Jakarta, jilid 3

Koentjaraningrat, 1974, Kebudayaan Mentalitet dan Pembangunan, Gramedia, Jakarta

Loren Bagus, 2005, Kamus Filsafat, Gramedia, Jakarta

Magnis-Suseno, F, 2003, Etika Jawa: Sebuah Analisa Falsafah tentang Kebijaksanaan Hidup Jawa., Gramedia, Jakarta, cet. 9

Soesmoro, K H., 2010, Keris Jawa Tradisional di Daerah Yogyakarta dan Surakarta, Kontinuitas dan Perubahannya, (Disertasi) Pascasarjana UGM, Yogyakarta 


\section{Catatan:}

${ }^{1}$ Daryono, 2007, Etos Dagang Orang Jawa Pengalaman Raja Mangkunagara IV, Pustaka Pelajar, Yogyakarta., hal V

2 Hadisiswaya, AM., 2009, Filosofi Wahyu Keraton Rahasia Dibalik Cerita, Simbolis dan Lambang Keraton Jawa, C.V. Sahabat, Klaten., hal 130

${ }^{3}$ Djoko Sukiman, 1983, Keris: Sejarah dan Fungsinya, Javanologi, Yogyakarta, hal 23

${ }^{4}$ Gustami, S.P., 2007, Butir-Butir Mutiara Estetika Timur, Ide Dasar Penciptan Seni Kriya Indonesia, Prasista, Yogyakarta, hal 17

${ }^{5}$ Loren Bagus, 2005, Kamus Filsafat, Gramedia, Jakarta, hal 672

6 Magnis-Suseno, F, 2003, Etika Jawa: Sebuah Analisa Falsafah tentang Kebijaksanaan Hidup Jawa., Gramedia, Jakarta, cet. 9, hal 6

${ }^{7}$ Magnis-Suseno, F, 2003, ibid, hal 14

8 Koentjaraningrat, 1974, Kebudayaan Mentalitet dan Pembangunan, Gramedia, Jakarta, hal 32

9 Hasan Sadhily, 1990, Ensiklopedia Indonesia, PT Ichtiar Baru, Jakarta, jilid 3, hal 1756

10 Soesmoro, K H., 2010, Keris Jawa Tradisional di Daerah Yogyakarta dan Surakarta, Kontinuitas dan Perubahannya, (Disertasi) Pascasarjana UGM, Yogyakarta, hal 118

11 Budisutrisna, 2009, Gambaran Manusia Dalam Keris, dalam Joko Siswanto (ed), Kearifan Nusantara, Kepel Press, Yogyakarta, hal 50

12 Harsrinuksmo, B., 2004, Ensiklopedia Keris, , Gramedia, Jakarta, cet.1 hal 27

${ }^{13}$ Gustami, Lok.cit, hal 56

${ }^{14}$ Magnis Suseno, lock cit., hal 86

${ }^{15}$ Magnis Suseno, 1984, Ibid, hal 39
16 Endraswara., S., 2010, Falsafah Hidup Jawa, Menggali Mutiara Kebijakan dari Intisari Filsafat Kejawen, Cakrawala, Yogyakarta, hal 172

${ }^{17}$ Magnes Suseno, ibid, hal 38

${ }^{18}$ Endraswara., S., 2010, lok.cit., hal 23 